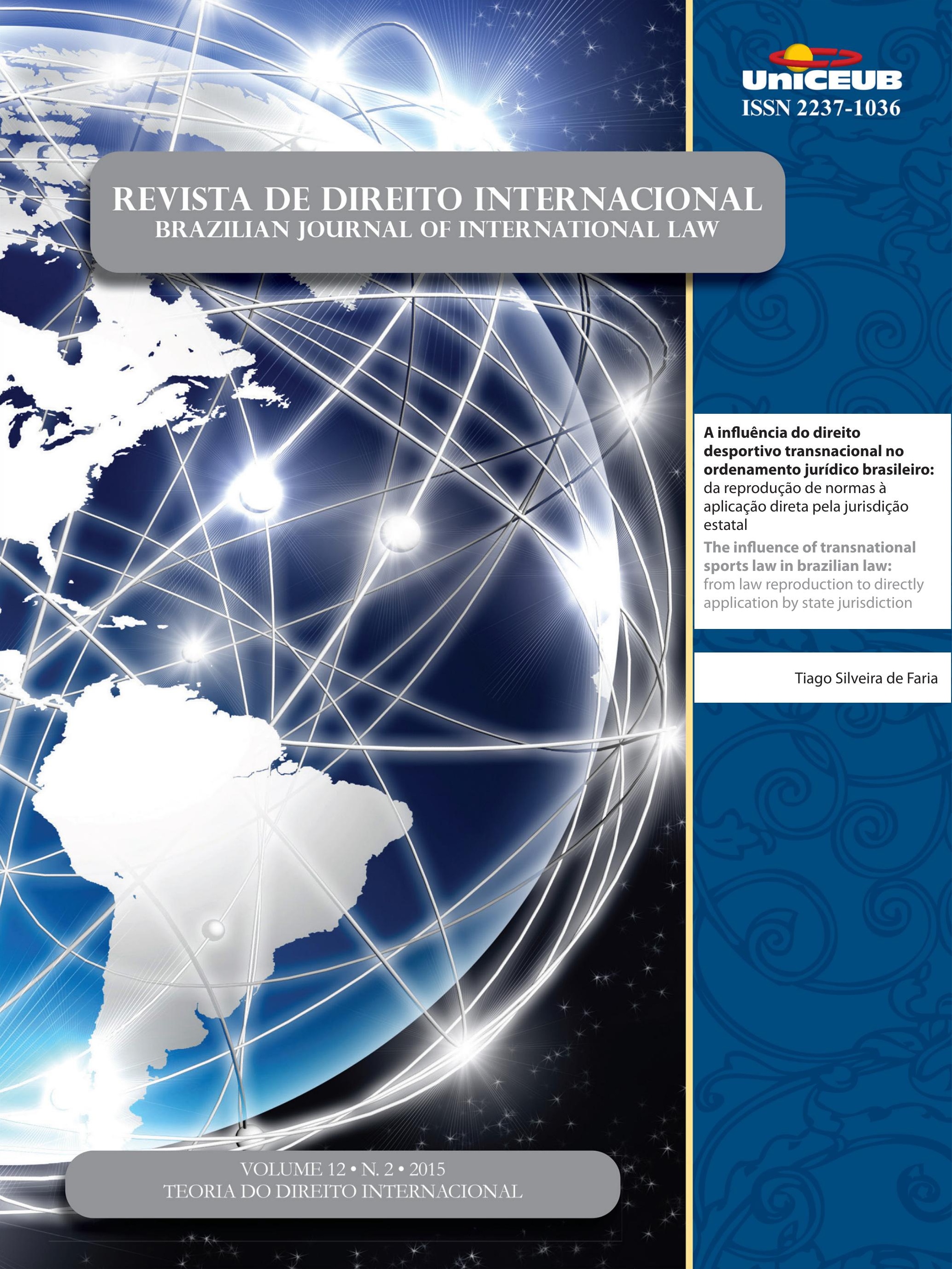




\section{Sumário}

CrôNiCAS DA ATUALIDADE do DiREITo INTERnACIONAL ..................................................... 2 Sarah Dayanna Lacerda Martins Lima, Carina Costa de Oliveira e Erika Braga

CrôniCas do Direito InternaCional dos InVESTIMENTOS ..............................................12 Nitish Monebhurrun

Por que voltar a Kelsen, o jurista do século XX ? 16 Inocêncio Mártires Coelho

O Princípio da Efetividade como conteúdo da norma fundamental (GrundNorm) DE KELSEN

Carlos Alberto Simões de Tomaz e Renata Mantovani de Lima

A JURIDIFICAÇÃo DE CONFLITOS POLÍTICOS NO DIREITO INTERNACIONAL PÚBLICO CONTEMPORÂ-

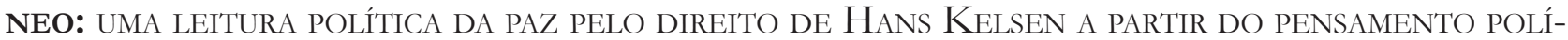
TICO De Claude Lefort

Arthur Roberto Capella Giannattasio

O SINCRETISMO TEÓRICO NA APROPRIAÇÃO DAS TEORIAS MONISTA E DUALISTA E SUA QUESTIONÁVEL UTILIDADE COMO CRITÉRIO PARA A CLASSIFICAÇÃO DO MODELO BRASILEIRO DE INCORPORA-

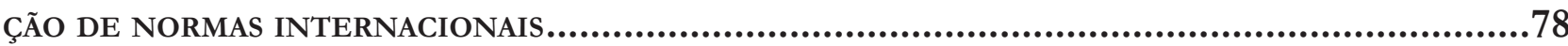
Breno Baía Magalhães

Direito Global em Pedaços: Fragmentação, Regimes e Pluralismo .98 Salem Hikmat Nasser

Por uma TeOria JURÍdica da INTEGRaÇão REgIONAL: A INTER-RELAÇÃO DiREITO INTERNO, DiREITO INTERNACIONAL PÚBLICO E DIREITO DA INTEGRAÇÃO Jamile Bergamaschine Mata Diz e Augusto Jaeger Júnior

A teOria DA INTERCONSTITUCIONALIDADE: UMA ANÁlISE COM BASE NA AMÉRICA LATINA...........160 Daniela Menengoti Ribeiro e Malu Romancini 
O DIÁLOGO HERMENÊUTICO E A PERGUNTA ADEQUADA À APLICAÇÃo DOS TRATADOS INTERNACIONAIS DE DIREITOS HUMANOS NO BRASIL: CAMINHOS PARA O PROCESSO DE INTERNACIONALIZAÇÃO

DA CONSTITUIÇÃO...................................................................................... 176

Rafael Fonseca Ferreira e Celine Barreto Anadon

O DIREITO COMPARADO NO STF: INTERNACIONALIZAÇÃO DA JURISDIÇÃO CONSTITUCIONAL BRASILEIRA

Carlos Bastide Horbach

THE PHILOSOPHY OF INTERNATIONAL LAW IN CONTEMPORARY SCHOLARSHIP: OVERCOMING NE-

GLIGENCE THROUGH THE GLOBAL EXPANSION OF HUMAN RIGHTS

Fabrício Bertini Pasquot Polido, Lucas Costa dos Anjos e Vinícius Machado Calixto

OpORTUNIDADES E DESAFIOS DAS TWAIL NO CONTEXTO LATINO-AMERICANO A PARTIR DE PERSPECTIVAS DOS POVOS INDÍGENAS AO DIREITO INTERNACIONAL

Fernanda Cristina de Oliveira Franco

Por Que uma ANÁlise ECONÔMICA Do DIREITO INTERNACIONAL PÚBLICO? DESAFIOS E PERSPECTIVAS DO MÉTODO NO BRASII

Gustavo Ferreira Ribeiro e Jose Guilherme Moreno Caiado

ANÁliSE ECONÔMICA do DIREITO INTERNACIONAL .263 Michele Alessandra Hastreiter e Luís Alexandre Carta Winter

RACIONALIDADE ECONÔMICA E OS ACORDOS BILATERAIS DE INVESTIMENTO 284 Michele Alessandra Hastreiter e Luís Alexandre Carta Winter

LOOKING FOR A BRICS PERSPECTIVE ON INTERNATIONAL LAW .304 Gabriel Webber Ziero

A INFLUÊNCIA DO DIREITO DESPORTIVO TRANSNACIONAL NO ORDENAMENTO JURÍDICO BRASILEIRO: DA REPRODUÇÃO DE NORMAS À APLICAÇÃO DIRETA PELA JURISDIÇÃO ESTATAL.......................3324 Tiago Silveira de Faria

CONVENCIONALIZAÇÃo DO DIREITO CIVIL: A APLICAÇÃo DOS TRATADOS E CONVENÇÕES INTERNACIONAIS NO ÂMBITO DAS RELAÇÕES PRIVADAS . 
NATIONAL JUdGES AND COURTS AS INSTITUTIONS FOR GLOBAL ECONOMIC GOVERNANCE 356

Juízes e tribunais nacionais como instituições para a governança global 356 Camilla Capucio

Is Trade Governance Changing? 371 Alberto do Amaral Júnior

OS FUNDOS ABUTRES: MEROS PARTICIPANTES DO CENÁRIO INTERNACIONAL OU SUJEITOS PERANTE O DIREITO INTERNACIONAL? 384

Guilherme Berger Schmitt

SHAREHOLDER AGREEMENTS IN PUBLICLY TRADED COMPANIES: A COMPARISON BETWEEN THE

U.S. AND BRAZIL. 402 Helena Masullo

REgulaÇÃo DO INVESTIMENTO ESTRANGEIRO DIRETO NO BRASIL: DA RESISTÊNCIA AOS TRATADOS BILATERAIS DE INVESTIMENTO À EMERGÊNCIA DE UM NOVO MODELO REGULATÓRIO 421 Fabio Morosini e Ely Caetano Xavier Júnior

DA QUALIFICAÇÃo JURÍDiCA dAS Distintas FORMAS DE PRESTAÇão TECNOLÓGICA: BREVE ANÁLISE DO MARCO REGULATÓRIO INTERNACIONAL

Daniel Amin Ferraz

REDEFINING TERRORISM: THE DANGER OF MISUNDERSTANDING THE MODERN WORLD'S GRAVEST THREAT

Jennifer Breedon

As EXECUÇões SELETIVAS E A RESPONSABILIZAÇÃo DE AGENTES TERRORISTAS 485 Alexandre Guerreiro

INTERNATIONAL CRIMINALS AND THEIR VIRTUAL CURRENCIES: THE NEED FOR AN INTERNATIONAL EFFORT IN REGULATING VIRTUAL CURRENCIES AND COMBATING CYBER CRIME Joy Marie Virga

Criminalidad transnacional organizada en el Ámbito del MERCOSUR: ¿Hacia un Derecho Penal Regional?. .528 Nicolás Santiago Cordini e Mariano Javier Hoet 
RUMO À INTERNACIONALIZAÇÃo DA PROTEÇÃO PENAL DO MEIO AMBIENTE: DOS ECOCRIMES AO ECOCÍDIO

Kathia Martin-Chenut, Laurent Neyret e Camila Perruso

Engaging the U.N. Guiding Principles on Business and Human Rights: the inter-AMERICAN COMMISSION ON HUMAN RIGHTS \& THE EXTRACTIVE SECTOR 571 Cindy S. Woods

O DIREITO HUMANO À COMUNICAÇÃo PRÉVIA E PORMENORIZADA DAS ACUSAÇÕES NOS PROCESSOS administrativos: O desprezo do Superior Tribunal de Justiça ao Pacto de San José da Costa Rica e À Corte Interamericana de Direitos Humanos .590

Daniel Wunder Hachem e Eloi Pethechust

A responsabilidade internacional do Brasil em FaCe do CONTRole de ConVENCionaliDADE EM SEDE DE DIREITOS HUMANOS: CONFLITO DE INTERPRETAÇÃO ENTRE A JURISDIÇÃO DA Corte Interamericana de Direitos Humanos e o Supremo Tribunal Federal quanto a LEI DE ANISTIA 612

Carla Ribeiro Volpini Silva e Bruno Wanderley Junior

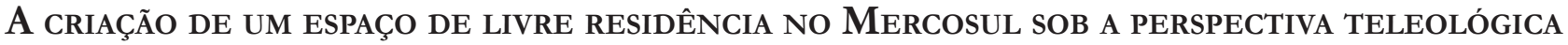
DA INTEGRAÇÃo REGIONAL: ASPECTOS NORMATIVOS E SOCIAIS DOS ACORDOS DE RESIDÊNCIA ....... 631

Aline Beltrame de Moura

A funcionalização como tendênCia evolutiva do Direito Internacional e sua conTRIBUIÇÃO AO REGIME LEGAL DO BANCO DE DADOS DE IDENTIFICAÇÃO DE PERFIL GENÉTICO NO BRASIL

Antonio Henrique Graciano Suxberger

O DIREITO INTERNACIONAL E A PROTEÇÃO DOS DIREITOS DE CRIANÇAS E DE ADOLESCENTES EM CONFLITO COM A LEI EM MOÇAMBIQUE

Bernardo Fernando Sicoche

ObTenÇão de PRovas no EXTERIOR: PARA ALÉM dA LEX FORI E LEX DiLigENTIAE. .685 André De Carvalho Ramos 
A Slight Revenge and a Growing Hope for Mauritius and the Chagossians: The UNClos Arbitral Tribunal's Award of 18 March 2015 on Chagos Marine Protected Area (Mauritius v. United Kingdom)

Géraldine Giraudeau

ANÁLISE DA RESPONSABILIDADE INTERNACIONAL DA UCRÂNIA POR VIOLAÇÃo DOS DIREITOS HUmanos na QUeda do voo da Malaysia Airlines (MH17). .728

Daniela Copetti Cravo

NatureZa JURÍdica do DESENVOLVIMENTO SUSTENTÁVEL No DIREITO INTERNACIONAL ........739 Pedro Ivo Diniz

A INFLUÊNCIA Da SOFT LAW NA FORMaÇão do DiREITo AMBIENTAL .767 Leonardo da Rocha de Souza e Margareth Anne Leister

As COMPLICADAS INTER-RELAÇÕES ENTRE OS SISTEMAS INTERNOS E INTERNACIONAIS DE PROTEÇãO DO DIREITO AO MEIO AMBIENTE SADIO. 785 José Adércio Leite Sampaio e Beatriz Souza Costa 


\title{
A influência do direito desportivo transnacional no ordenamento jurídico brasileiro: da reprodução de normas à aplicação direta pela jurisdição estatal*
}

\author{
The influence of transnational sports law in \\ brazilian law: from law reproduction to directly \\ application by state jurisdiction
}

Tiago Silveira de Faria**

\section{Resumo}

O artigo pretende analisar a influência do direito desportivo transnacional no ordenamento jurídico brasileiro, seja com base na reprodução de normas transnacionais oriundas das federações esportivas internacionais, por meio do processo legislativo convencional, seja por meio da aplicação direta do direito desportivo estrangeiro pela jurisdição estatal, este mais complexo e envolvendo uma necessária exposição do pluralismo jurídico, da fragmentação do direito e da hetero-regulação normativa que permeia o âmbito jurídico-desportivo. Posteriormente, ao se estudar a peculiar regra de conexão prevista na legislação desportiva estatal, abordar-se-á os elementos, os limites e os eventuais obstáculos para a aplicação do direito desportivo estrangeiro em território pátrio, assim como os possíveis critérios para solução de conflitos normativos, encerrando-se com estudo de casos, opção metodológica principal deste trabalho.

Palavras-chave: Direito desportivo transnacional. Brasil. Jurisdição estatal.

\section{Abstract}

The article aims to analyze the influence of transnational Sports Law in the Brazilian legal system, whether from the reproduction of transnational norms deriving from international sports federations through conventional legislative process, either through direct application of foreign Sports Law by the State jurisdiction, this case more complex, involving a necessary display of legal pluralism, fragmentation of law and hetero-normative regulation that pervades the legal and sports context. Later, when studying the peculiar connection rule in State Sports Legislation, will address them elements, limits and possible obstacles to the application of foreign Sports Law on home territory and the possible criteria for conflict resolution regulatory, ending up with a case study, main methodological option of this work.

Keywords: Transnational sports Law. Brazil. State jurisdiction.

** Especialista em Direito Empresarial pela PUCRS. Mestrando em Direito pela UNISINOS. Articulista e professor de Direito Desportivo. Advogado. E-mail: tiagosdefaria@ gmail.com
Recebido em 07/09/2015 Aprovado em 01/11/2015 


\section{SUMÁRIO}

1 Introdução; 2 Pluralismo jurídico, transnacionalidade e hetero-regulação no âmbito desportivo; 3 A reprodução de normas desportivas transnacionais pelo ordenamento jurídico brasileiro; 4 A aplicação direta do direito desportivo estrangeiro pela jurisdição estatal; 5 Estudo de casos; 6 Conclusão; Referências.

\section{INTRODUÇÃO}

No desporto, floresce um fenômeno semelhante ao que os teóricos da lex mercatoria têm identificado no campo do comércio internacional: a existência de ordenamentos jurídicos privados e autônomos em relação ao Estado, dentro de um pluralismo que caracteriza a pós-modernidade global. Em verdade, a globalização é caracterizada pelo fatos dos Estados não serem mais os centros do poder, doravante dispersos em uma sociedade fragmentada. ${ }^{1}$

Essa constatação traz à tona que, para o estudo das fontes do direito, é preciso voltar-se, também, para a produção normativa por grupos sociais particulares, segmentos da sociedade que, de forma crescente, competem com o poder legiferante do Estado-nação. ${ }^{2}$ Nessa concepção, o direito não se reduz a um conjunto de normas emanadas pelo Estado.

O direito desportivo talvez seja um dos exemplos mais claros de duplicidade das fontes normativas (hetero-regulação), porquanto, no mesmo sistema, gravitam normas de origem estatal e de origem privada, nem sempre em harmonia, mas que demonstram o pluralismo intrínseco a essa disciplina. De um lado, as normas "oficiais" do Estado-nação brasileiro; de outro, as normas transnacionais das federações esportivas internacionais. É possível dizer que essa normatividade transversal limita o poder e a soberania dos Estados, dentro dessa complexa rede transnacional que não conta mais com o direito estatal como única referência funcional, mas

1 JAYME, Erik. O direito internacional privado do novo milênio: a proteção da pessoa humana face à globalização. Cadernos do programa de pós-graduação em Direito, Porto Alegre, v. 1, n. 1, p. 133-146, mar. 2003. p. 86.

2 TEUBNER, Gunther. A Bukowina global sobre a emergência de um pluralismo jurídico transnacional. Revista de Ciências Sociais e Humanas, Piracicaba, v. 14, n. 33, p. 9-31, jan./abr. 2003. p. 10-11. baseia-se em diversos níveis de normatividade. ${ }^{3}$

A esse conjunto de normas desportivas transnacionais, originadas das federações esportivas internacionais, tem-se atribuído o neologismo de lex sportiva, de forma similar à lex mercatoria e outros fenômenos jurídicos similares.

Interessante notar que a influência da normatividade desportiva transnacional, perante o Estado-nação brasileiro, tem dois vieses: a reprodução de suas normas pelo ordenamento jurídico nacional; a aplicação direta da legislação transnacional pela jurisdição estatal.

A reprodução das normas transnacionais da Fédération Internationale de Football Association - FIFA pelo ordenamento jurídico brasileiro, e.g., demonstra a grande influência que, na fragmentação do direito, uma entidade desportiva privada pode alcançar ante a ordem jurídica "oficial".

De outra parte, a aplicação direta da normatividade desportiva transnacional em território pátrio, por meio de um elemento de conexão bastante peculiar, explicita a pluralidade de fontes normativas e reforça o poder dos regimes jurídicos autônomos na sociedade atual.

No entanto, quais são os elementos, limites e eventuais obstáculos para a aplicação do direito desportivo transnacional pela jurisdição estatal brasileira? Essas questões que, doravante, pretende-se explicitar, tendo por referencial teórico o pluralismo jurídico ordenado de Mireille Delmas-Marty.

\section{Pluralismo jurídico, transnacionalidade E HETERO-REGULAÇÃO NORMATIVA NO ÂMBITO DESPORTIVO}

Entre os valores básicos da pós-modernidade, destacam-se o pluralismo lato sensu, pluralismo de estilos de vida e a negação de uma pretensão universal à maneira própria de ser. Expressa a convivência, lado a lado, dos diferentes, do estrangeiro e dos contrapostos. A pluralidade reaparece como um valor jurídico (Rechtswert). Na

3 TEIXEIRA, Anderson Vichinkeski. Qual a função do estado constitucional em um constitucionalismo transnacional? In: STRECK, Lenio Luiz; ROCHA, Leonel Severo; ELGELMANN, Wilson (Org.). Constituição, sistemas sociais e hermenêutica: anuário do Programa de Pós-Graduação em Direito da UNISINOS. Porto Alegre: Livraria do Advogado, 2012. v. 9, p. 9-32. p. 9-10. 
linguagem do direito, o pluralismo significa ter à disposição alternativas, opções, possibilidades. ${ }^{4}$

A ascensão de ordens jurídicas privadas deslocadas do poder estatal é um ponto marcante e inegável da contemporaneidade, ainda que o direito (clássico) se oponha ferrenhamente à multiplicidade pela sua vocação a uma ordem unificada e hierarquizada. ${ }^{5}$ Assim, a tese do monismo jurídico encontra-se muito distante da realidade e da complexidade contemporânea. Com efeito, para o estudo das fontes do direito,

\begin{abstract}
deve ser ressaltado o poder normativo dos grupos sociais particulares, que nos dias de hoje se configuram como uma realidade solar. [...] Esses grupos sociais são fontes de normas, pois têm o poder de criar suas próprias ordenações jurídicas que garantem a consecução dos fins que pretendem atingir. [...] Como exemplo de ordenamentos jurídicos dos grupos sociais particulares podemos citar: o direito desportivo. ${ }^{6}$
\end{abstract}

O esporte, entendido com um fragmento autônomo da sociedade, exige uma enorme demanda por normas regulatórias, mas que não pode ser suprida por instituições vinculadas ao Estado-nação. Em vez disso, esse subsistema da sociedade satisfaz sua própria demanda recorrendo ao direito autônomo, i.e., criando seu próprio direito substantivo e suas fontes normativas, distantes da esfera legislativa nacional e dos tratados internacionais.

Para Gunther Teubner, só é possível compreender o pluralismo jurídico em sua real dimensão se abandonarmos a suposição de que o direito global extrai sua validade somente de processos legislativos e de sanções estatais, derivados de fontes jurídicas internas ao Estado ou de fontes jurídicas internacionais oficialmente sancionadas. Nessa linha, o direito global demanda uma exegese de fontes arquitetada em termos pluralistas, convergindo a sua atenção para processos espontâneos de formação do direito, que compõem uma nova espécie

4 JAYME, Erik. Visões para uma teoria pós-moderna do direito comparado. Cadernos do programa de pós-graduação em Direito, Porto Alegre, v. 1, n. 1, p. 115-131, mar. 2003. p. 118-119.

5 DELMAS-MARTY, Mireille. Três desafios para um direito mundial. Tradução de Fauzi Hassan Choukr. Rio de Janeiro: Lumen Juris, 2003. p. 99.

6 SIQUEIRA JR., Paulo Hamilton. Teoria do direito. 3. ed. São Paulo: Saraiva, 2012. p. 54.

7 TEUBNER, Gunther. Colisões de regimes: a busca vã por unidade jurídica na fragmentação do direito global. Revista Brasileira de Estudos Constitucionais, Belo Horizonte, v. 6, n. 21, p. 105-155, jan./ mar. 2012. p. 117. apartada do instituído pelos Estados. ${ }^{8}$

Essas ordens constituem-se "em autonomia relativa diante do Estado-nação, bem como diante da política internacional, setores distintos da sociedade mundial que produzem a partir de si mesmos ordenamentos jurídicos globais sui generis."”

Segundo Teubner, a fragmentação do direito na pós-modernidade transparece o fato incontroverso de que o Estado "deixou de ser o fundamento único de validade do poder e da lei". ${ }^{10} \mathrm{O}$ direito oficial do Estado não detém o monopólio das atenções, doravante disperso na fragmentação das diversas racionalidades sociais vigentes. ${ }^{11}$

Como Janus, deus romano das mudanças e tradições, "O pluralismo se apresenta agora com duas faces [...] direito e sociedade." 12

A globalização reforçou, ainda mais, o crescimento social e econômico do fenômeno esportivo, que é, por sua própria natureza, universal. Nesse contexto, Lorenzo Casini ${ }^{13}$ manifesta que o esporte tem criado uma série de regras jurídicas e de instituições esportivas transnacionais que se equiparam a uma ordem jurídica autônoma: "[...] which legal scholarship has varyingly referred to as 'International Sports Law', 'Global Sports Law' and lex sportiva (thus drawing a patent analogy with the lex mercatoria governing international trade)."

E prossegue o mesmo autor com a seguinte assertiva:

8 TEUBNER, Gunther. A Bukowina global sobre a emergência de um pluralismo jurídico transnacional. Revista de Ciências Sociais e Humanas, Piracicaba, v. 14, n. 33, p. 9-31, jan./abr. 2003. p. 11.

9 TEUBNER, Gunther. A Bukowina global sobre a emergência de um pluralismo jurídico transnacional. Revista de Ciências Sociais e Humanas, Piracicaba, v. 14, n. 33, p. 9-31, jan./abr. 2003. p. 10.

10 TEUBNER, Gunther. A Bukowina global sobre a emergência de um pluralismo jurídico transnacional. Revista de Ciências Sociais e Humanas, Piracicaba, v. 14, n. 33, p. 9-31, jan./abr. 2003. p. 23.

11 TEUBNER, Gunther. As duas faces de Janus: pluralismo jurídico na sociedade pós-moderna. In:___ (Org.). Direito, sistema e policontexturalidade. Piracicaba: UNIMEP, 2005. p. 79-104. p. 81.

12 TEUBNER, Gunther. As duas faces de Janus: pluralismo jurídico na sociedade pós-moderna. In:___ (Org.). Direito, sistema e policontexturalidade. Piracicaba: UNIMEP, 2005. p. 79-104. p. 81.

13 CASINI, Lorenzo. Sports law: a global legal order? Law \& Society Forum, Honolulu, 2012. p. 03. Disponível em: <http://ssrn.com/ abstract $=2079857>$. Acesso em: 07 jun. 2015. 
As far as international regimes consist of 'sets of implicit and explicit principles, norms, rules, and decision-making procedures around which actor expectations converge in a given issue-area', sports legal orders can be likened to the internationallevel 'private regimes', i.e. those regimes that are voluntarily formed and should be conceptually located beyond the mechanisms typically arising in international law. ${ }^{14}$

É nesse cenário que a lex sportiva se destaca entre os regimes jurídicos privados transnacionais, com a lex mercatoria e a lex digitalis. ${ }^{15}$

A lex mercatoria é a pioneira no tema, remontando à Idade Média, quando comerciantes a desenvolveram como um remédio jurídico à multiplicidade de leis feudais que inviabilizavam a segurança jurídica comercial. ${ }^{16}$

A lex sportiva constitui um fenômeno jurídico similar, porém, no âmbito do esporte, compreendendo o conjunto de normas desportivas transnacionais produzidas por organizações desportivas privadas como a Fédération Internationale de Football Association - FIFA. ${ }^{17}$

O conceito de norma transnacional (ainda) é bastante discutido doutrinariamente. Philip Jessup ${ }^{18}$, um dos primeiros juristas a empregar o termo em sua obra Transnational Law, de 1965, definiu norma transnacional como todo direito que regula ações ou eventos que transcendem as fronteiras nacionais, incluindo o direito internacional público e privado.

Essa concepção, todavia, foi alvo de críticas por destacar as tradicionais disciplinas de direito internacional, muito ligadas ao conceito dogmático de fonte estatal, embora Jessup já ressaltasse, à época, a complexidade da sociedade e a insuficiência desses ramos para tratar dos incipientes fenômenos jurídicos.

Hodiernamente, o direito transnacional caracteriza-se mais por sua "desterritorialização", com ênfase nas

14 CASINI, Lorenzo. Sports law: a global legal order? Law \& Society Forum, Honolulu, 2012. p. 05. Disponível em: <http://ssrn.com/ abstract $=2079857>$. Acesso em: 07 jun. 2015.

15 TEUBNER, Gunther. A Bukowina global sobre a emergência de um pluralismo jurídico transnacional. Revista de Ciências Sociais e Humanas, Piracicaba, v. 14, n. 33, p. 9-31, jan./abr. 2003. p. 11.

16 CASINI, Lorenzo. Sports law: a global legal order? Law \& Society Forum, Honolulu, 2012. p. 37. Disponível em: <http://ssrn.com/ abstract $=2079857>$. Acesso em: 07 jun. 2015.

17 LATTY, Franck. La lex sportiva: recherche sur le droit transnational. Leiden: Nijhoff, 2007. p. 37.

18 JESSUP, Philip C. Direito transnacional. Tradução de Carlos Ramires Pinheiro da Silva. São Paulo: Fundo de Cultura, 1965. p. 12. novas formas de relações jurídicas além do estado. A respeito, Roger Cotterrell lembra que o direito transnacional é conceitualmente distinto do nacional e internacional, "because its primary sources and addressees are neither nation state agencies nor international institutions founded on treaties or conventions, but private (individual, corporate or collective) actors involved in transnational relations." 19

A peculiaridade do direito desportivo, por sua vez, reside na hetero-regulação normativa, porquanto no mesmo sistema gravitam normas nacionais (de fonte estatal) e transnacionais (de fonte privada), nem sempre em harmonia. ${ }^{20}$

A natureza normativa híbrida é especialmente verificável no desporto, como lembra Casini': "The answer is that sports law is now far from being understood from a private law perspective alone, because it presents, rather, a mixed nature, in which a regulatory framework based on private autonomy constantly interacts with public law norms."

Temas antes regulados prioritariamente pelo direito doméstico, de forma crescente, passam a ser tutelados pelo direito transnacional, com base em normas com caráter extraterritorial. Trata-se de um novo cenário, marcado pela expansão do direito global, com uma intensificação dos processos transnacionais, em que o direito estatal se internacionaliza a partir da maior interação com regimes jurídicos privados. ${ }^{22}$ Criam-se arranjos institucionais para traduzir esses fenômenos jurídicos para a realidade local. É por meio desses processos contínuos de interação que se configura a identidade de um direito internacional como um direito próprio e sua efetividade torna-se interesse dos Estados e dos demais atores privados. Nem mesmo países mais isolados,

19 COTTERRELL, Roger. What is Transnational Law. Law \& Social Inquiry, London, v. 37, n. 2, p. 500-524, March 2012. Disponível em: <http://papers.ssrn.com/sol3/papers.cfm?abstract_ id=2021088 $>$. Acesso em: 04 ago. 2015.

20 No Brasil, por exemplo, temos a regulação estatal (Lei 9.615/98 - Lei Pelé). No âmbito internacional, os estatutos e regulamentos da FIFA. BRASIL. Lei 9.615, de 24 de marco de 1998. Institui normas gerais sobre desporto e dá outras providências. Disponível em: <http://www.planalto.gov.br/ccivil_03/LEIS/L9615consol.htm>. Acesso em: 26 jul. 2015.

21 CASINI, Lorenzo. Sports law: a global legal order? Law \& Society Forum, Honolulu, 2012. p. 18. Disponível em: <http://ssrn.com/ abstract $=2079857>$. Acesso em: 07 jun. 2015.

22 VARELLA, Marcelo D. Internacionalização do direito: direito internacional, globalização e complexidade. 2012. 606 f. Tese (LivreDocência em Direito Internacional) - Faculdade de Direito, Universidade de São Paulo, São Paulo, 2012. p. 105. Disponível em: $<$ https://www.uniceub.br/media/186548/MVarella.pdf >. Acesso em: 03 nov. 2015. 
como Coreia do Norte, Cuba ou Albânia, conseguem se manter alheios. $^{23}$

Os subsistemas jurídicos, porém, nem sempre avançam na mesma direção, tampouco na mesma velocidade. Certos ramos do direito, como o desportivo, internacionalizam-se com maior rapidez, fruto da forte influência transnacional a que seu subsistema está acoplado. Há um progressivo intercruzamento normativo na construção dos direitos nacionais, uma pluralidade de ordens normativas que se comunicam, embora sem o clássico sistema hierarquizado. ${ }^{24}$

A par da atual multiplicidade de fontes normativas, não é possível prescindir da forma tradicional de regulamentação normativa (estatal), modelo que igualmente não para de se construir e reforçar. ${ }^{25}$

Mireille Delmas-Marty consegue conjecturar, na aparente profusão anárquica de normas, oriundas das mais diferentes fontes, uma possibilidade de ordenamento, pois a abundância normativa da atualidade não representa necessariamente uma desregulamentação nem a submissão ou supressão do poder legiferante estatal, "mas um reemprego das normas segundo outros dispositivos, mais opacos e mais complexos". ${ }^{26}$ Longe de reduzir o papel cabível ao direito, esse fenômeno marca a aparição de um novo processo de encadeamento de normas, lastreado na fragilidade do princípio hierárquico.

De fato, no Brasil, a principal legislação desportiva estatal (Lei 9.615/98) prevê, de forma expressa, a hetero-regulação normativa, consoante a disposição legal do $\int 1^{\circ}$ do art. $1^{\circ}$ : "A prática desportiva formal é regulada por normas nacionais e internacionais e pelas regras de prática desportiva de cada modalidade, aceitas pelas respectivas entidades nacionais de administração do desporto." 27

23 VARELLA, Marcelo D. Internacionalização do direito: direito internacional, globalização e complexidade. 2012. 606 f. Tese (LivreDocência em Direito Internacional) - Faculdade de Direito, Universidade de São Paulo, São Paulo, 2012. p. 315. Disponível em: $<$ https://www.uniceub.br/media/186548/MVarella.pdf $>$. Acesso em: 03 nov. 2015.

24 DELMAS-MARTY, Mireille. Les forces imaginantes du droit II: le pluralisme ordonné. Paris: Seuil, 2006.

25 DELMAS-MARTY, Mireille. Três desafios para um direito mundial. Tradução de Fauzi Hassan Choukr. Rio de Janeiro: Lumen Juris, 2003. p. 80.

26 DELMAS-MARTY, Mireille. Les forces imaginantes du droit II: le pluralisme ordonné. Paris: Seuil, 2006. p. 72-73.

27 BRASIL. Lei 9.615, de 24 de marco de 1998. Institui normas gerais
É possível vislumbra-se duas formas distintas de aplicação das normas transnacionais desportivas em território pátrio: 1) a reprodução (parcial ou total) de normas desportivas transnacionais pelo ordenamento jurídico-desportivo brasileiro; 2) aplicação direta daquelas normas pelo juiz por meio de critérios provenientes do direito internacional privado, este último caso de maior complexidade.

Ambas as hipóteses podem ser inseridas no que Delmas-Marty denomina de pluralismo ordenado, em que, embora haja o reconhecimento da diversidade, marca heterogênea da ordem jurídica contemporânea, busca-se uma resposta à complexidade jurídica mundial, delineando as possibilidades de harmonização normativa sem a ilusória pretensão de unificá-la. ${ }^{28}$

\section{A RePRODUÇÃo DE NORMAS DESPORTIVAS TRANSNACIONAIS PELO ORDENAMENTO JURÍDICO BRASILEIRO}

Com uma frequência crescente, tem-se observado a reprodução de normas desportivas transnacionais, especialmente da FIFA, pela legislação estatal brasileira, por meio do processo legislativo ordinário.

Mireille Delmas-Marty classifica essas relações estabelecidas entre os diferentes sistemas jurídicos de internormatividade. São técnicas de relação e intercâmbio normativo num sentido prático, notadamente no que a autora francesa denomina de processos de "imitação", i.e., diferentes ordenamentos jurídicos buscando inspiração em outros para a produção normativa. ${ }^{29}$ É o direito privado transnacional como fonte de inspiração do direito estatal.

Convém registrar que o direito transnacional ingressa em cada país de maneira distinta, em geral com adequações às respectivas culturas e ordens jurídicas nacionais. A internacionalização de normas envolve um processo dinâmico e complexo de interações, em que a norma pode ser internalizada, no âmbito doméstico,

sobre desporto e dá outras providências. Disponível em: $<$ http:// www.planalto.gov.br/ccivil_03/LEIS/L9615consol.htm>. Acesso em: 26 jul. 2015.

28 DELMAS-MARTY, Mireille. Les forces imaginantes du droit II: le pluralisme ordonné. Paris: Seuil, 2006. p. 7-10.

29 DELMAS-MARTY, Mireille. Les forces imaginantes du droit II: le pluralisme ordonné. Paris: Seuil, 2006. p. 42. 
de forma quase idêntica à originária ou totalmente remodelada. ${ }^{30}$

No caso do Brasil, as normas desportivas transnacionais vêm sendo reproduzidas pelo ordenamento jurídico brasileiro de forma muito similar às originárias, o que demonstra o reconhecimento estatal da especialidade do subsistema desportivo privado transnacional.

Nesse sentido, o artigo 27-B da Lei 9.615/98 - Lei Pelé, inclú́do pela Lei $12.395 / 11^{31}$, é um exemplo claro dessa ilação:

Art. 27-B. São nulas de pleno direito as cláusulas de contratos firmados entre as entidades de prática desportiva e terceiros, ou entre estes e atletas, que possam intervir ou influenciar nas transferências de atletas ou, ainda, que interfiram no desempenho do atleta ou da entidade de prática desportiva, exceto quando objeto de acordo ou convenção coletiva de trabalho.

A previsão legal supratranscrita retrata, de maneira geral, a regra constante do art. 18 BIS do regulamento de transferência de jogadores da FIFA ${ }^{32}$, vigente desde a edição de 2008, que proíbe a interferência de terceiros em contratos de trabalho e transferências de atletas: "No club shall enter into a contract which enables the counter club/counter clubs, and vice versa, or any third party to acquire the ability to influence in employment and transfer-related matters its independence, its policies or the performance of its teams."

Da mesma forma, o artigo 29-A, introduzido na ordem jurídico-desportiva estatal pela citada Lei $12.395 / 11$, reproduz o mecanismo de solidariedade ${ }^{33}$

30 VARELLA, Marcelo D. Internacionalização do direito: direito internacional, globalização e complexidade. 2012. 606 f. Tese (LivreDocência em Direito Internacional) - Faculdade de Direito, Universidade de São Paulo, São Paulo, 2012. p. 115-116. Disponível em: $<$ https://www.uniceub.br/media/186548/MVarella.pdf $>$. Acesso em: 03 nov. 2015.

31 BRASIL. Lei 12.395, de 16 de março de 2011. Altera as Leis nos 9.615 , de 24 de março de 1998, que institui normas gerais sobre desporto. Disponível em: < http://www.planalto.gov.br/ccivil_03/_ ato2011-2014/2011/lei/112395.htm>. Acesso em: 09 ago. 2015.

32 FÉDÉRATION INTERNATIONALE DE FOOTBALL ASSOCIATION. Regulation on the status and transfer of players. Zurique, 2015. Disponível em: <http://resources.fifa.com/mm/ document/affederation/administration/01/06/30/78/statusinhalt_en_122007.pdf>. Acesso em: 26 jul. 2015.

33 Se um jogador é transferido onerosamente de clube durante a vigência do contrato de trabalho, $5 \%$ do valor a ser pago pelo clube cessionário (contratante) ao clube cedente deverá ser separado e distribuído entre os clubes que formaram o jogador entre os 12 e os 23 anos de idade. Este é o mecanismo de solidariedade (solidarity mechanism), instituto que visa compensar financeiramente os clubes que participaram da formação do atleta, o que torna possível a um pequeno clube brasileiro receber, anos mais tarde, uma participação "importado" do artigo 21 e do anexo V do regulamento de transferência de jogadores da entidade máxima do futebol, cujo inteiro teor está disponível no sítio oficial da FIFA desde a edição 2005.

Nesses casos, a legislação transnacional da FIFA foi adotada voluntariamente, de maneira planejada e com esforços de harmonização, pelo Estado-nação brasileiro. Tal incorporação da legislação transnacional ocorre por meio de "intermediários".

$\mathrm{Na}$ definição de Shaffer ${ }^{34}$, intermediários são pessoas físicas ou jurídicas, públicas ou privadas, que podem atuar em nível nacional ou regional, oferecendo múltiplas "portas de entrada" para a legislação transnacional. Eles ajudam a traduzir, adaptar e contextualizar as normas transnacionais aos contextos locais. Esses intermediários incluem representantes do governo, prestadores de serviços, acadêmicos, organizações não-governamentais, entidades privadas, líderes de movimentos sociais etc.

Em território pátrio, podemos identificar a Confederação Brasileira de Futebol - CBF, associação privada sem fins lucrativos, como a grande intermediária para o processo de incorporação da lex FIFA ao ordenamento jurídico brasileiro, juntamente, em nível regional, com as federações desportivas estaduais e os clubes. A CBF, igualmente, possui influência no Congresso Nacional, com deputados e senadores atentos aos seus interesses. $^{35}$

Não há dúvida de que a reprodução de normas transnacionais da FIFA, pelo ordenamento jurídico estatal brasileiro, é a melhor forma de prevenir conflitos e harmonizar os diferentes regimes jurídicos. Porém, isso nem sempre é possível, quer pela grande disparidade da dinâmica de produção normativa, quer pela divergência de interesses.

financeira sobre a vultosa venda de um atleta entre grandes clubes europeus.

34 SHAFFER, Gregory. Transnational legal process and state change: opportunities and constraints. Nova Iorque: Universidade of Minnesota, 2012. (Legal Studies Research Paper Series Research Paper, n. 1028). p. 35-36. Disponível em: <http://papers.ssrn.com/sol3/papers.cfm?abstract_id=1901952>. Acesso em: 26 jul. 2015.

35 REBELLO, Aiuri; CRUZ, José. "Bancada da bola" faz, pressão e tira CBF de projeto sobre dividas dos times. Brasília, 29 abr. 2014. Disponível em: <http://esporte.uol.com.br/futebol/ultimas-noticias/2014/04/29/bancada-da-bola-faz-pressao-e-tira-cbf-de-projeto-sobre-divida-dos-times.htm>. Acesso em: 26 jul. 2015. 


\section{A APLICAÇÃO DO DIREITO DESPORTIVO ESTRANGEIRO PELA JUSRISDIÇÃO ESTATAL}

A Constituição Federal de 1988 é relativamente omissa em relação à aplicação, em território pátrio, do direito estrangeiro, excetuando-se a incorporação de normas internacionais relativas a direitos humanos (art. $5^{\circ}, \int 2^{\circ}$, da $\mathrm{CF} / 88$ ), às convenções e aos tratados (art. 49, inciso I, e art. 84, inciso VIII, da CF/88), que estão especialmente contemplados, mas que retratam matéria majoritariamente de direito internacional público.

Para o restante do direito internacional e transnacional, todavia, são frequentes os questionamentos acerca do alcance dessas normas no direito interno, as quais tampouco figuram no rol legislativo do art. 59 da $\mathrm{CF} / 88{ }^{36}$

Nem mesmo para as organizações internacionais, assim entendidas aquelas que detêm alguma participação governamental, eg., ONU, OTAN, Mercosul etc., a situação é clara. Como lembra Dallari, ${ }^{37}$

\begin{abstract}
Se o acúmulo de discussão, embora volumoso, não possibilitou ainda que a legislação, doutrina $\mathrm{e}$ jurisprudência convergissem no reconhecimento de posição incontroversa para a disciplina da recepção das normas convencionais, no caso das decisões de organizações internacionais, tal debate nem sequer ganhou corpo.
\end{abstract}

A problemática adentra no campo do direito internacional privado - DIPr, que cuida de classificar ou qualificar a situação jurídica e determinar o direito aplicável à espécie. Em outras palavras, indica a lei material (nacional ou estrangeira) incidente no caso concreto.

No Brasil, a principal fonte interna do DIPr é a Lei de Introdução às Normas do Direito Brasileiro (LINDB), Decreto-Lei 4.657/42. ${ }^{38}$

O direito brasileiro está submetido ao princípio da territorialidade moderada/mitigada, i.e., no nosso território aplica-se, em regra, a lei brasileira. Havendo, no entanto, um elemento de conexão, aplica-se o direito

36 BENJAMIN, Daniela Arruda. A aplicação dos atos de organizações internacionais no ordenamento jurídico brasileiro. Brasília: Funag, 2014. p. 107.

37 DALLARI, Pedro B. A. Constituição e relacõoes internacionais. 2. ed. São Paulo: Saraiva, 2003. p. 119.

38 BRASIL. Decreto-Lei 4.657, de 04 de setembro de 1942. Lei de Introdução às normas do Direito Brasileiro. Disponível em: <http:/ / www.planalto.gov.br/ccivil_03/decreto-lei/Del4657.htm>. Acesso em: 31 jul. 2015. estrangeiro, desde que, nos termos do 17 da LINDB, as leis, atos e sentenças de outro país, bem como quaisquer declarações de vontade, não ofendam a soberania nacional, a ordem pública e os bons costumes. Por elemento ou regra de conexão entende-se as normas de direito internacional privado que indicam o direito aplicável às várias situações jurídicas conectadas a mais de um sistema legal. ${ }^{39}$

As principais regras de conexão estão dispostas na Lei de Introdução às Normas do Direito Brasileiro. No entanto, a vetusta legislação data de 1942 e a Lei 12.376/2010 apenas alterou seu campo de incidência, outrora restrito ao Código Civil..$^{40}$ Desse modo, o anacronismo da LINDB em relação aos novos fenômenos que permeiam o direito internacional privado exige a ampliação do foco de atenção para outras fontes normativas. ${ }^{41}$

Entre as normas de ligação previstas em legislações esparsas, encontra-se a regra de conexão desportiva disposta no $\int 1^{\circ}$ do art. $1^{\circ}$ da Lei 9.615/98: “A prática desportiva formal é regulada por normas nacionais e internacionais e pelas regras de prática desportiva de cada modalidade, aceitas pelas respectivas entidades nacionais de administração do desporto."

É preciso, no entanto, fazer uma importante distinção. A norma de conexão desportiva não tem a característica maniqueísta típica dos elementos de ligação do DIPr, mas um caráter holístico integrativo. Assim, essa regra de conexão não visa propriamente dirimir conflitos de leis no espaço, para muitos o cerne do direito internacional privado, e sim facultar a aplicação do direito desportivo internacional concomitantemente com a legislação nacional. $\mathrm{O}$ art. $3^{\circ}$, inciso III, da Lei Pelé reforça a hetero-regulação (nacional e internacional) do Direito Desportivo e seu caráter integrativo. ${ }^{42}$

39 DOLINGER, Jacob. Direito internacional privado: parte geral. 11. ed. Rio de Janeiro: Forense, 2014. p. 297.

40 Então denominada Lei de Introdução ao Código Civil (LICC). 41 BASSO, Maristela. Curso de direito internacional privado. 3. ed. São Paulo: Atlas, 2013. p. 49.

42 Art. $3^{\circ} \mathrm{O}$ desporto pode ser reconhecido em qualquer das seguintes manifestações:[...] III - desporto de rendimento, praticado segundo normas gerais desta Lei e regras de prática desportiva, nacionais e internacionais, com a finalidade de obter resultados e integrar pessoas e comunidades do País e estas com as de outras nações. BRASIL. Lei 9.615, de 24 de marco de 1998. Institui normas gerais sobre desporto e dá outras providências. Disponível em: <http:// www.planalto.gov.br/ccivil_03/LEIS/L9615consol.htm>. Acesso em: 26 jul. 2015. 
Como destaca Álvaro Melo Filho ${ }^{43}$,

Em suma, é a própria lei brasileira sobre desporto que impõe a obediência e acatamento às normas internacionais, o que implica no reconhecimento da autonomia desportiva dos entes internacionais, sem malferir ou derruir a soberania nacional.

Esse caráter integrativo permite estabelecer processos de coordenação normativa, segundo a linha teórica de Delmas-Marty, especialmente o que denomina de "harmonização por aproximação", que são movimentos ascendentes e descendentes entre o direito interno e o direito transnacional, uma troca normativa propensa à cooperação entre as diferentes fontes do direito. ${ }^{44}$ Essa forma de interação tem uma hierarquia dinâmica de ajustamentos e reajustamentos sucessivos. Ao mesmo tempo em que o Estado tende a manter uma margem nacional de aplicação de seu direito, ele também quer a aproximação com o estrangeiro, criando uma verdadeira dinâmica de forças que resultam em uma hierarquia que não é necessariamente de cima para baixo, mas que está em constante mutação. ${ }^{45}$

A norma de conexão desportiva brasileira parece se encaixar nesse conceito, sendo indireta e sui generis. Indireta porque não resolve o problema de direito material subjacente, apenas indica a legislação aplicável. Já a peculiaridade reside no fato de que, em vez de resolver o conflito de leis no espaço, tipificando as hipóteses e indicando uma única legislação aplicável, essa norma de conexão, paradoxalmente, amplia o direito material incidente e remete a solução, ainda que indiretamente, para a análise do caso concreto.

Note-se, ademais, que a regra de ligação desportiva é abstrata em relação ao direito estrangeiro aplicável, ao mencionar simplesmente "normas internacionais", o que, no singular ramo do direito desportivo, subentende-se o ordenamento jurídico-desportivo produzido pelas federações desportivas internacionais, a lex sportiva, e não as normas desportivas decorrentes do "direito oficial" dos demais Estados-nação.

Mas, como antes mencionado, a análise da eventual aplicação da lei desportiva estrangeira, concomitante-

43 MELO FILHO, Álvaro. O novo direito desportivo. São Paulo: Cultural Paulista, 2002. p. 70.

44 DELMAS-MARTY, Mireille. Les forces imaginantes du droit II: le pluralisme ordonné. Paris: Seuil, 2006. p. 70-100.

45 VELHO, Rafael Rott de Campos. O Mercosul e a política ambiental: modelos, inconsistências e alternativas. Revista de Direito Internacional, Brasília, v. 9, n. 3, p. 103-128, 2012. p. 110. mente ou não com a legislação nacional, dar-se-á no momento em que o órgão judicante apreciar o caso concreto. Isso porque pode haver antinomias entre a legislação nacional e internacional que impeçam a aplicação simultânea de ambas de modo harmônico, como parece ser o intuito da lei (mens legis).

Por antinomia jurídica tem-se a oposição que ocorre entre duas normas contraditórias, emanadas de autoridades competentes num mesmo âmbito normativo. Tercio Sampaio Ferraz Junior ainda acrescenta o fato de que o sujeito deve ficar em uma posição insustentável pela ausência ou inconsistência de critérios aptos a solucionar a incongruência, distinguindo, assim, a antinomia real (insolúvel) da antinomia aparente (solúvel). ${ }^{46}$

Um exemplo típico de conflito entre a lex FIFA e a legislação desportiva brasileira está no prazo máximo estipulado para o primeiro contrato profissional de um atleta de futebol. De acordo com o artigo 29 da Lei 9.615/98 - Lei Pelé:

Art. 29. A entidade de prática desportiva formadora do atleta terá o direito de assinar com ele, a partir de 16 (dezesseis) anos de idade, o primeiro contrato especial de trabalho desportivo, cujo prazo não poderá ser superior a 5 (cinco) anos.

Já o regulamento de transferências da FIFA só admite contratos profissionais, para menores de 18 anos, com prazo máximo de 03 (três) anos. É o que dispõe o artigo 18, item 2, in fine, do indigitado regulamento: "Players under the age of 18 may not sign a professional contract for a term longer than three years. Any clause referring to a longer period shall not be recognized."

Interessante notar que, dada a complexidade da norma de conexão desportiva, pode-se dizer que o direito privado internacional não está adequadamente preparado para enfrentar determinados conflitos normativos, especialmente quando o caso concreto atrai a competência jurisdicional da FIFA. ${ }^{47}$ Aqui, no entanto, restringir-se-á o estudo da aplicação do direito desporti-

46 FERRAZ JUNIOR, Tercio Sampaio. Introdução ao estudo do direito: técnica, decisão, dominação. 7. ed. São Paulo: Atlas, 2013. p. 179. 47 Via de regra, quando há algum "elemento internacional" envolvido, i.e., quando as partes em litígio (atletas, clubes, etc.) pertencem a diferentes associações (países, protetorados, etc.). Vide art. $1^{\circ}$ do regulamento de transferência da FIFA. FÉDÉRATION INTERNATIONALE DE FOOTBALL ASSOCIATION. Regulation on the status and transfer of players. Zurique, 2015. Disponível em: $<$ http://resources.fifa.com/mm/document/affederation/administration/01/06/30/78/statusinhalt_en_122007.pdf>. Acesso em: 26 jul. 2015. 
vo estrangeiro pela jurisdição estatal aos casos que não envolvam um "conflito de competência" com a entidade máxima do futebol, cujos critérios para a resolução de litígios são distintos e sui generis.

De outra parte, a legislação desportiva brasileira não estabelece nenhum tipo de critério para a solução de eventuais antinomias existentes entre as normas internas e internacionais, colocando-as, ainda que indiretamente, em um mesmo plano hierárquico da lei ordinária nacional ( $\int 1^{\circ}$ do art. $1^{\circ}$ da Lei 9.615/98).

Irrelevante, assim, que a Fédération Internationale de Football Association (FIFA) seja uma associação privada de direito suíço, já que a legislação desportiva brasileira não faz distinção hierárquica entre suas próprias normas ordinárias e as transnacionais, justamente por compreender a sistemática desportiva mundial, em que as entidades privadas internacionais exercem um controle global sobre os respectivos esportes. Tal fato, aliás, é corroborado pela proteção constitucional conferida às organizações desportivas pelo art. 217, inciso I, da Carta Federal de $1988 .^{48}$

Partindo-se do pressuposto de que ambas as legislações estão num mesmo âmbito hierárquico e normativo, quais os critérios para a solução de eventuais antinomias?

Considerando o fato de que não existe propriamente um conflito de competência, mas apenas de direito material aplicável (nacional ou internacional), em tese, não há óbice para a resolução dos conflitos normativos por meio de critérios historicamente corporificados pela legislação nacional e internacional, sobretudo os critérios da especialidade (lex specialis derogat generalis), cronológico (lex posterior derogat priori) e hierárquico ${ }^{49}$ (lex superior

48 Art. 217. É dever do Estado fomentar práticas desportivas formais e não-formais, como direito de cada um, observados: I - a autonomia das entidades desportivas dirigentes e associações, quanto a sua organização e funcionamento. BRASIL. Constituição (1988). Constituição da Republica Federativa do Brasil. Disponível em: <http:/ / www.planalto.gov.br/ccivil_03/Constituicao/Constituicao.htm>. Acesso em: 3 fev. 2016.

49 O critério hierárquico tem sido mais utilizado para resolver as antinomias em nível interno, especialmente no embate entre a legislação desportiva estatal e a Constituição Federal, v.g., vínculo desportivo (art. 28, \5 50, inciso II, da Lei 9.615/98) e o livre exercício da profissão (art. 5, inciso XIII, da CF/88). BRASIL. Constituição (1988). Constituição da Republica Federativa do Brasil. Disponível em: <http://www.planalto.gov.br/ccivil_03/Constituicao/Constituicao. htm>. Acesso em: 3 fev. 2016. Sobre o tema, consultar: FARIA, Tiago Silveira de. A persistência da inconstitucionalidade do vínculo desportivo na lei 12.395/2011. Jornal Trabalbista Consulex, Brasília, v. derogat inferiori). Essas regras resolveriam as antinomias aparentes.

Para as antinomias reais, assim entendidas aquelas em que há também conflito entre os próprios critérios, e.g., norma anterior-especial e outra posterior-geral, a doutrina elaborou metarregras: 1) lex inferiori non derogat priori superiori; 2) lex posteriori generalis non derogat priori speciali. ${ }^{50}$

Segundo Martti Koskenniemi, os critérios de solução de conflitos normativos, oriundos do "direito tradicional", são igualmente úteis no campo internacional: "This is why it is useful to have regard to the wealth of techniques in the traditional law for dealing with tensions or conflicts between legal rules and principles." 51 Aliás, as regras de especialidade e cronológica são amplamente empregadas pelo direito internacional, enquanto o critério de hierarquia é menos utilizado. $^{52}$

Evidentemente, para viabilizar a análise das possíveis soluções para os conflitos normativos, de acordo com as regras citadas, torna-se imperiosa a estrita observância do art. 14 da LINDB $^{53}$, pois, em regra, o juiz não conhece a lei estrangeira (exceção ao brocardo jurídico iura novit curia) e a prova do texto e da vigência incumbe à parte que alega.

O desconhecimento da legislação estrangeira, da regra de conexão desportiva, assim como a vontade de aplicar a lex fori, talvez sejam os principais motivos para o receio e a desconformidade de aplicação das normas desportivas estrangeiras pela jurisdição estatal. A respei-

28, p. 6-8, 2011.

50 FERRAZ JUNIOR, Tercio Sampaio. Introdução ao estudo do direito: técnica, decisão, dominação. 7. ed. São Paulo: Atlas, 2013. p. 178. 51 KOSKENNIEMI, Martti. Fragmentation of international law: difficulties arising from the diversification and expansion of international law. In: INTERNATIONAL LAW COMMISSION, 58., 2006. Report of the Study Group of the International Law Commission... Geneve: United Nations, 2006. p. 15-16. Available at: <http://legal. un.org/ilc/documentation/english/a_cn4_1682.pdf>. Access : 3 Feb. 2016.

52 KOSKENNIEMI, Martti. Fragmentation of international law: difficulties arising from the diversification and expansion of international law. In: INTERNATIONAL LAW COMMISSION, 58., 2006. Report of the Study Group of the International Law Commission... Geneve: United Nations, 2006. p. 20. Available at: <http://legal. un.org/ilc/documentation/english/a_cn4_1682.pdf>. Access : 3 Feb. 2016.

53 Art. 14.Não conhecendo a lei estrangeira, poderá o juiz exigir de quem a invoca prova do texto e da vigência. BRASIL. DecretoLei 4.657, de 04 de setembro de 1942. Lei de Introdução às normas do Direito Brasileiro. Disponível em: < http://www.planalto.gov.br/ ccivil_03/decreto-lei/Del4657.htm>. Acesso em: 31 jul. 2015. 
to, lembra Gaudemet-Tallon, ${ }^{54}$

Ora, a vontade de aplicar sua própria lei, sem mesmo vislumbrar a possibilidade de aplicar uma lei estrangeira, me parece ser a característica de uma ordem jurídica ainda imatura, que quer se impor de forma imperialista ao invés de procurar uma boa coordenação internacional.

No mesmo sentido, não parece antiquada a visão de Clóvis Beviláqua, ${ }^{55}$
Para que seja possível determinar, com isenção de espírito, qual a sede de uma relação de direito, é necessário partir dessa ideia de elevada de uma comunhão de direitos entre os diferentes povos, que se acham em contato frequente. Essa comunhão de direito realiza-se pelo acordo dos Estados em admitir que possam ser aplicadas, por seus juízes, leis originariamente estrangeiras, o que não é absolutamente resultado de simples benevolência, ato revogável de uma vontade arbitrária, mas consequência natural do desenvolvimento próprio do direito.

Torna-se relevante, assim, a par da previsão hetero-regulativa da legislação esportiva brasileira, o estudo de casos de aplicação das normas desportivas transnacionais pela jurisdição estatal, na medida em que a matéria (ainda) transita em um caminho nebuloso, reforçando a necessidade de pesquisa empírica. Afinal, como ressalta José Rodrigo Rodriguez" "Não há crítica do direito sem análise das instituições reais, ou seja, sem pesquisas empíricas que as sustentem [...]."

\section{Estudo de CAsos}

A essência do estudo de caso consiste em iluminar uma decisão ou um conjunto de decisões: por que elas são tomadas, como elas são implementadas e com que resultado.

A escolha de casos múltiplos tem vantagens metodológicas em comparação com o projeto de caso único, pois é considerado mais robusto pela lógica da replica-

54 GAUDEMET-TALLON, Héléne. Le pluralisme en droit international privé: richesses et faiblesses (le funambule et l'arc-en-ciel) : cours general. Leiden: M. Nijhoff, 2006. (Recueil des Cours de l' Académie de Droit International de la Haye, n. 312).p. 269.

55 BEVILÁQUA, Clóvis. Princípios elementares de direito internacional privado. Rio de Janeiro: Rio, 1978. p. 273.

56 RODRIGUEZ, José Rodrigo. Fuga do direito: um estudo sobre o direito contemporâneo a partir de Franz Neumann. São Paulo: Saraiva, 2009. p. 140. ção. ${ }^{57}$ Após a descoberta de um resultado, a prioridade subsequente é replicá-lo.

Para Robert Yin ${ }^{58}$, “cada estudo de caso individual consiste em um estudo completo, no qual a evidência convergente é procurada em relação aos fatos e às conclusões do caso; as conclusões de cada caso são, então, consideradas a informação que precisa ser replicada."

Por outro lado, não há que se confundir pesquisa de levantamento ou amostragem com estudo de caso, pois esse método emprega a generalização analítica, enquanto aquela o método de generalização estatística. No estudo de caso, o pesquisador busca generalizar um conjunto determinado de resultados, pela lógica de replicação, a alguma teoria mais ampla (generalização analítica). ${ }^{59}$

O âmbito do presente estudo de casos concentrar-se-á em decisões oriundas da justiça comum de primeira e de segunda instâncias do Estado do Rio Grande do Sul. No que toca à seleção dos casos, a triagem foi realizada por meio de pesquisa jurisprudencial no sítio oficial do Tribunal de Justiça do Rio Grande do Sul - TJRS ${ }^{60}$, pelo método de "palavras-chave". ${ }^{61}$ Em que pese os casos selecionados representem processos públicos, os nomes das partes foram omitidos com a transcrição apenas das respectivas letras iniciais.

A análise do caso iniciará pela sentença de primeira instância mediante a elaboração de um relatório. Posteriormente, far-se-á a transcrição, ipsis litteris, do ponto nevrálgico da decisão, com o intuito de dar maior confiabilidade ao estudo; por fim, as conclusões conectadas à teoria de base. Na sequência, será apresentada a decisão de segunda instância com a manutenção ou reforma da sentença originária e a exposição da ratio decidendi.

57 HERRIOT, Robert E.; FIRESTONE, William A. Multisite qualitative policy research: optimizing description and generalizability. Florida: Educational Researcher, 1983. p. 14-19.

58 YIN, Robert K. Estudo de caso: planejamento e métodos. Trad. Ana Thorell. 4. ed. Porto Alegre: Bookman, 2010. p. 80.

59 YIN, Robert K. Estudo de caso: planejamento e métodos. Trad. Ana Thorell. 4. ed. Porto Alegre: Bookman, 2010. p. 66.

60 RIO GRANDE DO SUL. Tribunal de Justiça. Pesquisa de Jurisprudência. Porto Alegre, 2015. Disponível em: < http://www.tjrs.jus. br/site/>. Acesso em: 2 ago. 2015.

61 Selecionada a pesquisa de jurisprudência "inteiro teor", com a seguintes palavras-chave: "regulamento e FIFA". Posteriormente, fez-se uma nova triagem analítica dos casos a partir das decisões disponíveis. Para acesso às sentenças de primeira instância, utilizou-se o link "consulta processual" inserindo os números dos processos de segundo grau disponíveis e acesso aos links "ver dados de primeiros grau" e "ver sentença". 
O primeiro caso trazido à baila será o denominado "caso-piloto", 62 , assim entendido aquele que abarca a teoria de base de forma mais abrangente possível, buscando-se, após, a replicação em outro caso similar.

Primeiro caso: Processo no 001/1.10.0280529-6. ${ }^{63}$

Relatório:

T. V. e G. C., dizendo-se agentes de jogadores de futebol, ajuizaram ação judicial de cobrança contra o atleta R. C. O. Narraram os autores terem firmado com o réu, em 26 de julho de 2009, contrato de prestação de serviços, com exclusividade, em todos os assuntos pertinentes a sua carreira de jogador de futebol profissional, pelo prazo determinado de dois anos. A remuneração dos agentes foi estipulada, contratualmente, em $10 \%$ dos rendimentos brutos auferidos pelo atleta por contratos de trabalho firmados durante a vigência do contrato de agenciamento. Os agentes aduziram que o atleta descumpriu o contrato de agenciamento ao firmar, sem o conhecimento daqueles, contrato de trabalho com um clube húngaro e, posteriormente, com dois clubes brasileiros, igualmente sem lhes pagar a remuneração estipulada.

O atleta demandado, por sua vez, alegou que os autores não prestaram os serviços contratados, notadamente não tiveram qualquer participação nos contratos de trabalho firmados pelo réu durante a vigência do contrato de agenciamento. Aduziu, ainda, a ilegitimidade específica do autor G. C. para exercer a profissão de agente de jogadores, já que não seria credenciado junto às entidades desportivas pertinentes.

$\mathrm{Na}$ fundamentação da sentença, o magistrado atestou a incontrovérsia da contratação dos agentes pelo atleta, passando a analisar a atividade de agente de jogadores exercida pelos autores. No tema, a sentença considerou que ambos os agentes não tinham as credenciais necessárias para exercer o ofício, nos termos do art. 104, incisos I e III, do Código Civil. ${ }^{64}$

62 YIN, Robert K. Estudo de caso: planejamento e métodos. Trad. Ana Thorell. 4. ed. Porto Alegre: Bookman, 2010. p. 118-119.

63 RIO GRANDE DO SUL. Tribunal de Justiça. Processo Civil. Processo 001/1.10.0280529-6. Decima Sexta Vara Cível. Autores: Tomás Vier; Gabriel Caraver. Réu: Rychely Cantanhede de Oliveira. Porto Alegre, 15 de janeiro de 2013. Disponível em: <http:// www.tjrs.jus.br/site_php/consulta/download/exibe_doc1g_oracle.php?id_comarca=porto_alegre\&ano_criacao $=2013 \& \mathrm{cod}_{-}$ documento=130792\&tem_campo_tipo_doc $=S>$. Acesso em: 2 ago. 2015.

64 Art. 104. A validade do negócio jurídico requer: I - agente ca-
Para tanto, o julgador referiu que deve ser observada, no caso em exame, a legislação especial que regula as relações contratuais atinentes às atividades desportivas, especificamente a Lei 9.615/98 - Lei Pelé, que prevê, em seu artigo $1^{\circ}, \Omega 1^{\circ}$, a obediência de normas nacionais e internacionais.

Transcreve-se o trecho o ponto nevrálgico da sentença para o presente estudo:

[...] Tais regras específicas ditadas por lei ou mesmo regulamentos internacionais, no caso, possui plena vigência no ordenamento jurídico brasileiro, pois, além do próprio país assim prever, como frisado no artigo $1^{\circ}, \int 1^{\circ}$, inciso I (sic) da Lei Pelé, o próprio artigo $9^{\circ}$ da Lei de Introdução às Normas do Direito Brasileiro - LINDB, alterada pela Lei 12.376 de 2010, é enfático ao afirmar que quando a obrigação depende de forma essencial, esta deverá ser observada, admitindo-se as peculiaridades de lei estrangeira quanto aos requisitos extrínsecos do ato.

Imperioso frisar, ainda, que os regulamentos estrangeiros, leis e atos de outros países apenas não terão eficácia no caso de ofensa à soberania nacional, a ordem pública e os bons costumes (artigo 17, Lei 12.376/2010), o que não é o caso dos autos.

Então, não há qualquer impeditivo legal para não observância de ato editado pela FIFA no que tange à capacidade de pessoas físicas para agenciamento de jogadores perante clubes desportivos, os quais devem estar devidamente cadastrados para desempenho destas atividades.

Os autores não são agentes credenciados junto à Federação Internacional, consoante se observa na relação acostada pelo próprio réu (folhas 71 a 96).

Portanto, não poderiam os demandantes exercer qualquer agenciamento de jogadores perante clubes nacionais ou internacionais ou entabular qualquer negociação contratual para a atividade como representante do réu. É o que se infere junto ao Regulamento da FIFA, órgão que administra a modalidade de negociações entre jogadores de futebol e clubes agenciados por terceiros, documento juntado pelo réu às folhas 98 a 113, cumprindo o que preceitua o artigo 14 da LINDB exceção ao aforismo iuria novit curia. $[\text {... }]^{65}$

paz; [...] III - forma prescrita ou não defesa em lei. BRASIL. Lei $N^{o}$ 10.406, de 10 de janeiro de 2002. Institui o Código Civil. Disponível em: <http://www.planalto.gov.br/ccivil_03/leis/2002/L10406. htm>. Acesso em: 03 fev. 2016.

65 RIO GRANDE DO SUL. Tribunal de Justiça. Processo Civil. Processo 001/1.10.0280529-6. Decima Sexta Vara Cível. Autores: Tomás Vier; Gabriel Caraver. Réu: Rychely Cantanhede de Oliveira. Porto Alegre, 15 de janeiro de 2013. Disponível em: <http:// www.tjrs.jus.br/site_php/consulta/download/exibe_doc1g_oracle.php?id_comarca $=$ porto_alegre\&ano_criacao $=2013 \& \mathrm{cod}_{-}$ documento=130792\&tem_campo_tipo_doc=S>. Acesso em: 2 
Assim fundamentando, a sentença considerou o contrato de agenciamento nulo, julgando improcedente a demanda.

\section{Conclusões:}

A sentença aplicou o direito estrangeiro, especificamente os regulamentos da FIFA, mediante a regra de conexão estabelecida no art. $1^{\circ}, \int 1^{\circ}$, da Lei 9.615/98. Em uma interpretação sistemática da legislação brasileira e internacional: Código Civil (art. 104), Lei Pelé (art. 1º,$\$$ $1^{\circ}$ ) e Regulamentos da FIFA, buscou-se a compatibilidade num todo estrutural, em um paralelo da teoria das fontes. ${ }^{66}$

O decisum referiu, ainda, que o réu trouxe a prova da existência do direito estrangeiro (Regulamento da FIFA), cumprindo com a exigência inserta no art. 14 da $\operatorname{LINDB}^{67}$, e que o indigitado regulamento não contrariava o art. 17 da $\operatorname{LINDB}^{68}$, motivo pelo qual não haveria óbice a sua aplicação de forma concomitante e harmônica com a legislação nacional (ausência de antinomias ou ofensa à ordem pública e a soberania).

Para a sentença, como a validade do negócio jurídico requer agente capaz e forma prescrita ou não defesa em lei (art. 104 do CC), ratificada a forma essencial pelo art. $9^{\circ}$ da LINDB, os autores não cumpriram com a exigência de credenciamento junto ao órgão que regula a atividade (FIFA), nos termos do regulamento dessa entidade aplicável por força do art. $1^{\circ}, \sqrt{ } 1^{\circ}$, da Lei Pelé.

Da sentença de primeira instância, houve interposição de recurso de apelação. ${ }^{69} \mathrm{O}$ acórdão manteve a sen-

ago. 2015.

66 FERRAZ JUNIOR, Tercio Sampaio. Introdução ao estudo do direito: técnica, decisão, dominação. 7. ed. São Paulo: Atlas, 2013. p. 256. 67 Art. 14.Não conhecendo a lei estrangeira, poderá o juiz exigir de quem a invoca prova do texto e da vigência. BRASIL. DecretoLei 4.657, de 04 de setembro de 1942. Lei de Introdução às normas do Direito Brasileiro. Disponível em: <http:/ /www.planalto.gov.br/ ccivil_03/decreto-lei/Del4657.htm>. Acesso em: 31 jul. 2015.

68 Art. 17. As leis, atos e sentenças de outro país, bem como quaisquer declarações de vontade, não terão eficácia no Brasil, quando ofenderem a soberania nacional, a ordem pública e os bons costumes. BRASIL. Decreto-Lei 4.657, de 04 de setembro de 1942. Lei de Introdução às normas do Direito Brasileiro. Disponível em: <http:/ / www.planalto.gov.br/ccivil_03/decreto-lei/Del4657.htm>. Acesso em: 31 jul. 2015

69 RIO GRANDE DO SUL. Tribunal de Justiça. Recurso de apelação Cível. Processo Cível $n^{0} 70054439807$. Décima Sexta Câmara Cível. Recorrentes: Tomás Vier; Gabriel Caraver. Recorrido: Rychely Cantanhede de Oliveira. Relator: Des. Paulo Sergio Scarparo. Porto Alegre, 25 de julho de 2013. Disponível em: <http:// www.tjrs.jus.br/site_php/consulta/download/exibe_documento. php?ano $=2013 \&$ codigo $=1248582>$. Acesso em: 2 ago. 2015. tença de improcedência, mas por motivo diverso: ausência de comprovação dos serviços prestados e quebra do princípio da boa-fé objetiva. Quanto à fundamentação da sentença recorrida antes transcrita, o acórdão assim dispôs:

[...]Nesse ponto, convém salientar que não se deixa de reconhecer a razoabilidade do argumento - trazido aos autos pelo demandado a acolhido pela sentenciante - de que haveria nulidade do contrato, em razão de não serem os demandantes credenciados junto à FIFA. Afirmam os réus que haveria nulidade do contrato por não terem os autores credenciamento, bem como por inobservância das normas administrativas dessa entidade, no que pertine à utilização de formulários padronizados de contratação entre agente e atleta e entre agente e clubes de futebol associadas.

Todavia, independentemente das regras e formalidades da FIFA, releva, no caso ora sob a análise, é relevante notar que a validade de todo e qualquer contrato, no âmbito do direito privado, pressupõe que sejam observados tanto a função social do contrato quanto o princípio da boa-fé objetiva (arts. 421 e 422 do Código Civil). [... $]^{70}$

Desse modo, embora o acórdão tenha adotado fundamentos diversos para julgar improcedente a demanda, não invalidou a ratio decidendi a quo. Convém registrar, por fim, que o processo transitou em julgado sem recurso para as instâncias superiores (STJ e STF).

Segundo caso: Processo no $001 / 1.06 .0246425-4^{71}$

Relatório:

B. C. F., na condição de agente de jogadores autorizado pela FIFA, ajuizou ação de indenização contra o atleta C. C. D., alegando, em suma, que o jogador profissional lhe outorgou poderes, com exclusividade, para representá-lo em negociações com clubes de futebol europeus. O autor aduziu que, após diversas tratativas, trouxe uma proposta de trabalho para o atleta requerido de um clube italiano, que fora aceita pelo jogador. No

70 RIO GRANDE DO SUL. Tribunal de Justiça. Recurso de apelação Cível. Processo Cível no 70054439807. Décima Sexta Câmara Cível. Recorrentes: Tomás Vier; Gabriel Caraver. Recorrido: Rychely Cantanhede de Oliveira. Relator: Des. Paulo Sergio Scarparo. Porto Alegre, 25 de julho de 2013. Disponível em: <http:// www.tjrs.jus.br/site_php/consulta/download/exibe_documento. php?ano $=2013 \&$ codigo $=1248582>$. Acesso em: 2 ago. 2015 .

71 RIO GRANDE DO SUL. Tribunal de Justiça. Apelação Cível. Processo 001/1.06.0246425-4. Terceira Vara Cível Autor: Bernardo Chlaem Filho. Réu: Christian Corrêa Dionisío. Porto Alegre, 09 de fevereiro de 2007. Disponível em: <http://www.tjrs.jus.br/site_php/ consulta/download/exibe_doc1g_oracle.php?id_comarca=porto_ alegre\&ano_criacao $=2007 \&$ cod_documento $=126719 \&$ tem_campo_tipo_doc $=S>$. Acesso em: 2 ago. 2015. 
entanto, o atleta decidiu, de última hora, não concretizar a oferta laboral, optando por entabulá-la com outro clube da Alemanha, por meio de agente desportivo diverso, descumprindo, assim, a cláusula de exclusividade concedida. Desse modo, o autor postulou, a título de indenização por dano material, pagamento da comissão a que teria direito no clube italiano, equivalente a $10 \%$ do valor do contrato de trabalho ofertado e recusado pelo atleta; pleiteou, ainda, indenização por danos morais diante do abalo à sua imagem e credibilidade no mercado desportivo.

C. C. D., em contestação, alegou que o autor, enquanto agente de jogadores credenciado pela FIFA, não cumpriu com as exigências insertas no regulamento que norteia a atividade. $\mathrm{O}$ atleta reconheceu que o autor, de fato, trouxe uma proposta inicial de trabalho de um clube italiano, mas que teria recusado; uma segunda proposta trazida pelo autor, do mesmo clube e com melhores condições financeiras, não continha carimbo e assinatura dos dirigentes responsáveis, elementos mínimos de credibilidade, motivo pelo qual teria igualmente rejeitado e optado por encetar contrato de trabalho com outro clube europeu, por meio de outro agente. Por fim, aduziu que a comissão de 10\% sobre o contrato de trabalho só seria devida em caso de concretização do negócio com o clube italiano, o que não ocorreu.

A lide comportou julgamento antecipado, pela ausência de provas em audiência, na forma do art. 330, inciso I, do Código de Processo Civil.

$\mathrm{Na}$ fundamentação da sentença, o magistrado considerou que o regulamento de agentes de jogadores da FIFA era aplicável ao caso dos autos e que o autor efetivamente descumpriu diversos preceitos contidos nesse regulamento. Aduziu, ainda, que a atividade de agente de jogadores é de risco, sendo devida a remuneração somente em caso de efetivação do contrato de trabalho. No caso dos autos, o autor só demonstrou a existência de negociações preliminares, sem um desfecho positivo do pacto laboral.

Transcreve-se o trecho o ponto nevrálgico da sentença para o presente estudo:

[...] De pronto destaco que, não obstante os argumentos lançados pelo autor, no sentido de que a legislação a ser aplicada ao caso dos autos deva primar pelos ditames da lei civil em geral, é inevitável, como supedâneo das razões de decidir, a aplicação do Regulamento dos Agentes de Jogadores de fls. 48/60, expedido pela FIFA, trazido aos autos através de tradução por profissional juramentado.

Com isso, não há o afastamento do ordenamento jurídico pátrio, mas a observância do que já foi regulamentado pelo órgão competente à atividade desportiva, naquilo que não afrontar os preceitos e princípios que regem o ordenamento jurídico nacional. Em outras palavras, se aplica a Lei Nacional (Constituição Federal e Código Civil), mas também se considera o regulamento da entidade internacional, FIFA, no que não afrontar os preceitos e princípios dispostos no ordenamento jurídico pátrio. [...]

Por isso, a observância das normas específicas, ainda que não niveladas à lei civil, para dirimir as controvérsias advindas da relação entre o agente e o jogador de futebol. [... $]^{72}$

Assim, com base no descumprimento do regulamento de agentes de jogadores da FIFA, cujos artigos afrontados são irrelevantes para o presente estudo, e diante da ausência de concretização do contrato de trabalho entre o atleta e o clube italiano, o juiz julgou a ação indenizatória improcedente.

\section{Conclusões}

Houve a aplicação do direito desportivo estrangeiro pelo juiz nacional, especificamente o regulamento de agentes de jogadores da FIFA, trazido aos autos por tradutor juramentado. Todavia, não foi mencionada a existência de algum elemento de conexão para a incidência direta daquela normatividade transnacional. Optou-se, diante da anomia da legislação estatal brasileira acerca da atividade de agente de jogadores, por aplicar as normas da FIFA, naquilo que não afrontasse os preceitos e princípios do ordenamento jurídico nacional, em uma interpretação indireta do art. 17 do LINDB. Por fim, a par da aplicação dos regulamentos da FIFA, fez-se uma consideração sobre uma (suposta) hierarquia da lei estatal brasileira em relação à lei privada estrangeira.

Da sentença de primeira instância, houve interposição de recurso de apelação. ${ }^{73} \mathrm{O}$ acórdão manteve a

72 RIO GRANDE DO SUL. Tribunal de Justiça. Apelação Cível. Processo 001/1.06.0246425-4. Terceira Vara Cível Autor: Bernardo Chlaem Filho. Réu: Christian Corrêa Dionisío. Porto Alegre, 09 de fevereiro de 2007. Disponível em: <http://www.tjrs.jus.br/site_php/ consulta/download/exibe_doc1g_oracle.php?id_comarca=porto_ alegre\&ano_criacao $=2007 \&$ cod_documento $=126719 \&$ tem_campo_tipo_doc=S>. Acesso em: 2 ago. 2015.

73 RIO GRANDE DO SUL. Tribunal de Justiça. Recurso de apelação Cível. Processo Cível 70019936756. Quinta Câmara Cível. Recorrentes: Bernardo Chlaem Filho. Recorrido: Christian Corrêa Dionisío. Relator: Des. Paulo Roberto Felix. Porto Alegre, 04 de junho de 2008. Disponível em: <http://www.tjrs.jus.br/site_php/consulta/ download $/$ exibe_documento.php? ano $=2008 \&$ codigo $=700574>$. 
sentença de improcedência, pelos seus próprios fundamentos, com a transcrição, ipsis litteris, de toda a fundamentação originária.

Convém registrar, por fim, que houve a interposição de recurso especial pelo autor para o Superior Tribunal de Justiça - STJ, inadmitido pelo TJRS por questões processuais. Contra essa decisão de inadmissibilidade recursal, o autor interpôs, ainda, agravo de instrumento para o STJ, sendo negado provimento ao recurso por decisão monocrática, ${ }^{74}$ igualmente por questões processuais que são despiciendas à controvérsia objeto do presente estudo, com o consequente trânsito em julgado.

\section{Considerações finais}

A fragmentação do direito é uma marca da sociedade contemporânea, especialmente pelo surgimento de setores sociais especializados, que reclamam para si um direito autônomo com as suas próprias regras e instituições. Segmentos da sociedade que, de forma crescente, competem com o poder legiferante do Estado-nação. Assim, o direito não se reduz a um conjunto de normas emanadas pelo Estado, mas reclama um pluralismo de fontes normativas. É como um rio caudaloso que, após uma forte chuva, arrasta a tudo e a todos.

Nesse contexto, novos fenômenos jurídicos, que caracterizam o direito global, ganham força, v.g., a lex sportiva, ordenamento jurídico-desportivo transnacional produzido por entidades privadas sem participação governamental.

Tais ordens jurídicas privadas, que procuram se manter afastadas do direito oficial do Estado-nação, paradoxalmente, estão influenciando a legislação estatal, quer pela reprodução de normas transnacionais mediante processos legislativos convencionais, quer pela aplicação direta do direito desportivo estrangeiro.

Sob a perspectiva do Estado brasileiro, esses proces-

Acesso em: 3 fev. 2016.

74 BRASIL. Superior Tribunal de Justiça. Agravo de instrumento. AI n 1.155.400 - RS (2009/0025521-9). Agravante: Bernardo Chlaen Filho. Agravado: Christian Corrêa Dionisío. Decisão monocrática. Relator: Min. Honildo Amaral de Mello Castro. Brasília, 17 de julho de 2009. Disponível em: <https://ww2.sti.jus.br/processo/revista/ documento $/$ mediado $/$ ?componente $=\mathrm{MON} \&$ sequencial $=5784530$ $\&$ num_registro $=200900255219 \&$ data $=20090807 \&$ tipo $=0 \&$ format $\mathrm{o}=\mathrm{PDF}>$. Acesso em: 9 ago. 2015. sos de reprodução da normatividade jurídico-desportiva transnacional e de aplicação direta pela jurisdição estatal traduzem-se em tentativas de harmonização do direito oficial com o direito desportivo transnacional, criando-se arranjos institucionais para traduzi-lo ou aplicá-lo internamente. $^{75}$

No entanto, quanto à aplicação do direito desportivo transnacional pela jurisdição estatal, ainda há certa recalcitrância por uma série de motivos, dentre eles o desconhecimento da peculiar regra de conexão desportiva e seu funcionamento, assim como uma vontade, quiçá natural, de aplicar a lex fori escudada pela segurança do brocardo iura novot curia.

O estudo empírico de casos, porém, revelou que a jurisdição estatal, incisivamente de primeira instância, tem aplicado as normas transnacionais desportivas em uma leitura contemporânea do pluralismo jurídico, conquanto por meio de critérios disformes.

$\mathrm{O}$ primeiro caso conectou-se à teoria de base de forma mais abrangente, utilizando a norma de conexão desportiva de acordo com a mens legis, ou seja, buscando a compatibilidade e a aplicação concomitante de normas desportivas nacionais e transnacionais. A decisão de segunda instância (acórdão), embora tenha reconhecido expressamente a razoabilidade dos fundamentos da sentença originária quanto à aplicação do direito desportivo transnacional, optou por utilizar argumentos diversos para manter a improcedência da demanda, calcados exclusivamente no Código Civil.

Já no segundo caso estudado, a sentença de primeira instância aplicou as normas desportivas estrangeiras de forma concomitante à legislação estatal, naquilo que não a afrontasse, mas sem mencionar o elemento de conexão para a aplicação do direito desportivo estrangeiro. Referiu, ademais, uma (suposta) hierarquia entre a legislação civil brasileira em relação às normas desportivas transnacionais: lex superior derogat inferiori. A decisão de segunda instância (acórdão), nesse caso, manteve a sentença de improcedência pelos seus próprios fundamentos, com a transcrição, ipsis litteris, de toda a fundamentação originária.

A despeito de certa discrepância na ratio decidendi dos casos analisados, percebe-se que a legislação desportiva transnacional ganha espaço no ordenamento jurídico

75 DELMAS-MARTY, Mireille. Les forces imaginantes du droit II: le pluralisme ordonné. Paris: Seuil, 2006. p. 69. 
estatal, tanto pela reprodução de normas transnacionais por meio do processo legislativo convencional, quanto pela aplicação direta da normatividade desportiva estrangeira pela jurisdição nacional.

Assim, paradoxalmente, é o direito "oficial" do Estado-nação que, deliberadamente, cede espaço para a normatividade transnacional, enquanto esse subsistema mantém-se equidistante do ordenamento jurídico estatal, com sua pretensão de autonomia e auto-regulação.

\section{REFERÊNCIAS}

BASSO, Maristela. Curso de direito internacional privado. 3. ed. São Paulo: Atlas, 2013.

BENJAMIN, Daniela Arruda. A aplicação dos atos de organizações internacionais no ordenamento jurídico brasileiro. Brasília: Funag, 2014.

BEVILÁQUA, Clóvis. Princípios elementares de direito internacional privado. Rio de Janeiro: Rio, 1978.

BRASIL. Constituição (1988). Constituição da Republica Federativa do Brasil. Disponível em: < http:/ / www.planalto.gov.br/ccivil_03/Constituicao/Constituicao.htm>. Acesso em: 3 fev. 2016.

BRASIL. Decreto-Lei 4.657, de 04 de setembro de 1942. Lei de Introdução às normas do Direito Brasileiro. Disponível em: <http://www.planalto.gov.br/ccivil_03/ decreto-lei/Del4657.htm>. Acesso em: 31 jul. 2015.

BRASIL. Lei 12.395, de 16 de março de 2011. Altera as Leis nos 9.615, de 24 de março de 1998, que institui normas gerais sobre desporto. Disponível em: <http:/ / www.planalto.gov.br/ccivil_03/_ato2011-2014/2011/ lei/112395.htm>. Acesso em: 09 ago. 2015.

BRASIL. Lei 9.615, de 24 de marco de 1998. Institui normas gerais sobre desporto e dá outras providências. Disponível em: <http://www.planalto.gov.br/ccivil_03/ LEIS/L9615consol.htm>. Acesso em: 26 jul. 2015.

BRASIL. Lei $N^{0}$ 10.406, de 10 de janeiro de 2002. Institui o Código Civil. Disponível em: <http://www.planalto. gov.br/ccivil_03/leis/2002/L10406.htm>. Acesso em: 03 fev. 2016.

BRASIL. Superior Tribunal de Justiça. Agravo de instrumento. AI no 1.155.400 - RS (2009/0025521-9). Agravante: Bernardo Chlaen Filho. Agravado: Christian
Corrêa Dionisío. Decisão monocrática. Relator: Min. Honildo Amaral de Mello Castro. Brasília, 17 de julho de 2009. Disponível em: < https://ww2.stj.jus.br/processo $/$ revista $/$ documento $/$ mediado $/$ ?componente $=\mathrm{M}$ ON\&sequencial $=5784530 \&$ num_registro $=200900255$ $219 \&$ data $=20090807 \&$ tipo $=0 \&$ formato $=P D F>$. Aces so em: 9 ago. 2015.

CASINI, Lorenzo. Sports law: a global legal order? Law \& Society Forum, Honolulu, 2012. Disponível em: $<$ http:/ /ssrn.com/abstract $=2079857>$. Acesso em: 07 jun. 2015.

COTTERRELL, Roger. What is Transnational Law. Law \& Social Inquiry, London, v. 37, n. 2, p. 500-524, March 2012. Disponível em: <http://papers.ssrn.com/ sol3/papers.cfm?abstract_id $=2021088>$. Acesso em: 04 ago. 2015.

DALLARI, Pedro B. A. Constituição e relações internacionais. 2. ed. São Paulo: Saraiva, 2003.

DELMAS-MARTY, Mireille. Les forces imaginantes $d u$ droit II: le pluralisme ordonné. Paris: Seuil, 2006.

DELMAS-MARTY, Mireille. Três desafios para um direito mundial. Tradução de Fauzi Hassan Choukr. Rio de Janeiro: Lumen Juris, 2003.

DOLINGER, Jacob. Direito internacional privado: parte geral. 11. ed. Rio de Janeiro: Forense, 2014.

FARIA, Tiago Silveira de. A persistência da inconstitucionalidade do vínculo desportivo na lei 12.395/2011. Jornal Trabalbista Consulex, Brasília, v. 28, p. 6-8, 2011.

FÉDÉRATION INTERNATIONALE DE FOOTBALL ASSOCIATION. Regulation on the status and transfer of players. Zurique, 2015. Disponível em: < http:// resources.fifa.com/mm/document/affederation/administration/01/06/30/78/statusinhalt_en_122007. pdf>. Acesso em: 26 jul. 2015.

FERRAZ JUNIOR, Tercio Sampaio. Introdução ao estudo do direito: técnica, decisão, dominação. 7. ed. São Paulo: Atlas, 2013.

GAUDEMET-TALLON, Héléne. Le pluralisme en droit international privé: richesses et faiblesses (le funambule et l'arc-en-ciel): cours general. Leiden: M. Nijhoff, 2006. (Recueil des Cours de l' Académie de Droit International de la Haye, n. 312).

HERRIOT, Robert E.; FIRESTONE, William A. Multisite qualitative policy research: optimizing description and 
generalizability. Florida: Educational Researcher, 1983.

JAYME, Erik. O direito internacional privado do novo milênio: a proteção da pessoa humana face à globalização. Cadernos do programa de pós-graduação em Direito, Porto Alegre, v. 1, n. 1, p. 133-146, mar. 2003.

JAYME, Erik. Visões para uma teoria pós-moderna do direito comparado. Cadernos do programa de pós-graduação em Direito, Porto Alegre, v. 1, n. 1, p. 115-131, mar. 2003.

JESSUP, Philip C. Direito transnacional. Tradução de Carlos Ramires Pinheiro da Silva. São Paulo: Fundo de Cultura, 1965.

KOSKENNIEMI, Martti. Fragmentation of international law: difficulties arising from the diversification and expansion of international law. In: INTERNATIONAL LAW COMMISSION, 58., 2006. Report of the Study Group of the International Law Commission... Geneve: United Nations, 2006. Available at: <http://legal. un.org/ilc/documentation/english/a_cn4_1682.pdf> . Access: 3 Feb. 2016.

LATTY, Franck. La lex sportiva: recherche sur le droit transnational. Leiden: Nijhoff, 2007.

LATTY, Franck. Transnational sports law. The International Sports Law Journal, Haye, n. 1-2, p. 34-38, Jan./April 2011.

MELO FILHO, Álvaro. O novo direito desportivo. São Paulo: Cultural Paulista, 2002.

REBELLO, Aiuri; CRUZ, José. "Bancada da bola" faz pressão e tira CBF de projeto sobre dividas dos times. Brasília, 29 abr. 2014. Disponível em: < http:/ / esporte.uol.com. br/futebol/ultimas-noticias/2014/04/29/bancada-dabola-faz-pressao-e-tira-cbf-de-projeto-sobre-dividados-times.htm>. Acesso em: 26 jul. 2015.

RIO GRANDE DO SUL. Tribunal de Justiça. Apelação Cível. Processo 001/1.06.0246425-4. Terceira Vara Cível Autor: Bernardo Chlaem Filho. Réu: Christian Correa Dionísio. Porto Alegre, 09 de fevereiro de 2007. Disponível em: <http://www.tjrs.jus.br/site_php/ consulta/download/exibe_doc1g_oracle.php?id_ comarca $=$ porto_alegre\&ano_criacao $=2007 \& c o d$ documento=126719\&tem_campo_tipo_doc $=S>$. Acesso em: 2 ago. 2015.

RIO GRANDE DO SUL. Tribunal de Justiça. Pesquisa de Jurisprudência. Porto Alegre, 2015. Disponível em: $<$ http://www.tjrs.jus.br/site/>. Acesso em: 2 ago. 2015.
RIO GRANDE DO SUL. Tribunal de Justiça. Processo Civil. Processo 001/1.10.0280529-6. Decima Sexta Vara Cível. Autores: Tomás Vier; Gabriel Caraver. Réu: Rychely Cantanhede de Oliveira. Porto Alegre, 15 de janeiro de 2013. Disponível em: < http:// www.tjrs.jus.br/site_php/consulta/download/exibe_ doc1g_oracle.php?id_comarca=porto_alegre\&ano_ criacao $=2013 \&$ cod_documento $=130792 \&$ tem_campo_tipo_doc $=S>$. Acesso em: 2 ago. 2015.

RIO GRANDE DO SUL. Tribunal de Justiça. Recurso de apelação Cível. Processo Civel 70019936756. Quinta Câmara Cível. Recorrentes: Bernardo Chlaem Filho. Recorrido: Christian Correa Dionísio. Relator: Des. Paulo Roberto Felix. Porto Alegre, 04 de junho de 2008. Disponível em: < http://www.tjrs.jus. br/site_php/consulta/download/exibe_documento. php?ano $=2008 \&$ codigo $=700574 \mathrm{P}$. Acesso em: $3 \mathrm{fev}$. 2016.

RIO GRANDE DO SUL. Tribunal de Justiça. Recurso de apelação Cível. Processo Civel n ${ }^{\circ} 70054439807$. Décima Sexta Câmara Cível. Recorrentes: Tomás Vier; Gabriel Caraver. Recorrido: Rychely Cantanhede de Oliveira. Relator: Des. Paulo Sergio Scarparo. Porto Alegre, 25 de julho de 2013. Disponível em: < http://www.tjrs.jus. br/site_php/consulta/download/exibe_documento. php?ano $=2013 \&$ codigo $=1248582>$. Acesso em: 2 ago. 2015.

RODRIGUEZ, José Rodrigo. Fuga do direito: um estudo sobre o direito contemporâneo a partir de Franz Neumann. São Paulo: Saraiva, 2009.

SHAFFER, Gregory. Transnational legal process and state change: opportunities and constraints. Nova Iorque: Universidade of Minnesota, 2012. (Legal Studies Research Paper Series Research Paper, n. 10-28). Disponível em: <http://papers.ssrn.com/sol3/papers.cfm?abstract_ id $=1901952>$. Acesso em: 26 jul. 2015.

SIQUEIRA JR., Paulo Hamilton. Teoria do direito. 3. ed. São Paulo: Saraiva, 2012.

TEIXEIRA, Anderson Vichinkeski. Qual a função do estado constitucional em um constitucionalismo transnacional? In: STRECK, Lenio Luiz; ROCHA, Leonel Severo; ELGELMANN, Wilson (Org.). Constituição, sistemas sociais e hermenêutica: anuário do Programa de PósGraduação em Direito da UNISINOS. Porto Alegre: Livraria do Advogado, 2012. v. 9, p. 9-32.

TEUBNER, Gunther. As duas faces de Janus: plura- 
lismo jurídico na sociedade pós-moderna. In: (Org.). Direito, sistema e policontexturalidade. Piracicaba: UNIMEP, 2005. p. 79-104.

TEUBNER, Gunther. Colisões de regimes: a busca vã por unidade jurídica na fragmentação do direito global. Revista Brasileira de Estudos Constitucionais, Belo Horizonte, v. 6, n. 21, p. 105-155, jan./mar. 2012.

TEUBNER, Gunther. A Bukowina global sobre a emergência de um pluralismo jurídico transnacional. Revista de Ciências Sociais e Humanas, Piracicaba, v. 14, n. 33, p. 9-31, jan./abr. 2003.

VARELLA, Marcelo D. Internacionalização do direito: di- reito internacional, globalização e complexidade. 2012. 606 f. Tese (Livre-Docência em Direito Internacional) - Faculdade de Direito, Universidade de São Paulo, São Paulo, 2012. Disponível em: <https://www.uniceub. br/media/186548/MVarella.pdf $>$. Acesso em: 03 nov. 2015.

VELHO, Rafael Rott de Campos. O Mercosul e a política ambiental: modelos, inconsistências e alternativas. Revista de Direito Internacional, Brasília, v. 9, n. 3, p. 103128, 2012.

YIN, Robert K. Estudo de caso: planejamento e métodos. Trad. Ana Thorell. 4. ed. Porto Alegre: Bookman, 2010. 
Para publicar na Revista de Direito Internacional, acesse o endereço eletrônico www.rdi.uniceub.br ou www.brazilianjournal.org.

Observe as normas de publicação, para facilitar e agilizar o trabalho de edição. 